\title{
Evaluation of Athrixia bush tea for cytotoxicity, antioxidant activity, caffeine content and presence of pyrrolizidine alkaloids
}

\section{L.J. McGaw ${ }^{a}$, V Steenkamp ${ }^{b}$ and J.N. Eloff ${ }^{a}$}

${ }^{a}$ Phytomedicine Programme, Department of Paraclinical Sciences, Faculty of Veterinary

Science, University of Pretoria, Private Bag X04, Onderstepoort 0110, South Africa

${ }^{b}$ Department of Pharmacology, School of Medicine, Faculty of Health Sciences, University of Pretoria, PO Box 2034, Pretoria 0001, South Africa

\begin{abstract}
In South Africa, Athrixia phylicoides DC. (bush tea) is widely used as a beverage, cough remedy and purgative. The commercialization of this tea in a similar vein to rooibos (Aspalathus linearis), is being considered. Traditional infusions and decoctions, as well as water and ethanol extracts, were prepared and screened. A related species, Athrixia elata Sond. (daisy tea), was included in many of the assays as a comparison. Extracts of Athrixia phylicoides and Athrixia elata were tested for toxic effects to brine shrimp larvae and the Vero kidney cell line. In both assays, the traditional preparations and aqueous extracts had little effect, but the ethanol extracts were relatively toxic. Antioxidant activity comparable to that found in rooibos was established. No detectable levels of caffeine were present in the Athrixia extracts following analysis using TLC and I/HCl spray reagent. Neither screening using spectrophotometry nor confirmation using gas chromatography-mass spectrometry analyses showed evidence of pyrrolizidine alkaloids in Athrixia phylicoides. Although a wider range of studies needs to be conducted prior to commercialization, these results support the development of bush tea as a healthy alternative to caffeine-containing beverages.
\end{abstract}


Abbreviations: ABTS, 2,2'-azinobis(3-ethylbenzothiazoline-6-sulfonic acid); DPPH, 1,1-diphenyl-2-picryl-hydrazyl; GC-MS, gas chromatography-mass spectrometry; I/HCl, iodine hydrochloric acid; MEM, minimal essential medium; MTT, 3-[4,5dimethylthiazol-2yl]-2,5-diphenyltetrazolium bromide; PA, pyrrolizidine alkaloid; TEAC, trolox equivalent antioxidant capacity; TLC, thin layer chromatography; Trolox, 6-hydroxy-2,5,7,8-tetramethylchromane-2-carboxylic acid

\section{Article Outline}

1. Introduction

2. Materials and methods

2.1. Collection of plant material

2.2. Preparation of extracts

2.2.1. Cytotoxicity testing, antioxidant activity and phenolic content

2.2.2. Caffeine detection

2.2.3. Pyrrolizidine alkaloid screening

2.3. Experimental procedures

2.3.1. Cytotoxicity assay

2.3.2. Brine shrimp larval mortality assay

2.3.3. Antioxidant assay

2.3.4. Phenolic content

2.3.5. Caffeine detection

2.3.6. Pyrrolizidine alkaloid screening

3. Results

4. Discussion

Acknowledgements

References

\section{Introduction}

There are 14 species of the genus Athrixia, nine of which are found in South Africa (Leistner, 2000). Athrixia phylicoides DC. (Asteraceae) is an aromatic shrub found in 
mountainous areas and the grassland of the eastern parts of South Africa (Pooley, 1998). A decoction of leaves and twigs is widely used as a "tea" by local communities-hence the name bush tea. Root decoctions of this species are also taken as purgatives and cough remedies (Watt and Breyer-Brandwijk, 1962). Plant infusions are used by the Zulus as blood purifiers and to treat sores and boils (Hutchings et al., 1996). The Vhavenda drink extracts made from the leaves and roots as anthelmintics (Mabogo, 1990) and credit the tea with aphrodisiac properties (Van Wyk and Gericke, 2000). The leaves and twigs of a related species, Athrixia elata, are used to prepare a beverage known as daisy tea (Van Wyk and Gericke, 2000). For this reason, the plant was included in part of the present study for interest and comparative purposes.

Although the usage of Athrixia tea has declined over time with the availability of commercially produced teas, the plant is considered to have economic potential as a herbal infusion (Van Wyk and Gericke, 2000). Two surveys were conducted to assess the local demand for the tea. The rural survey revealed that 68 of the 92 people interviewed in the Wolkberg region of the Limpopo Province still consume the tea, but that only $8 \%$ use it for its medicinal properties. In the urban survey, which was conducted in Soweto, Mamelodi and Marabastad (Gauteng Province), 83 of the 150 respondents knew the plant; 51 use it as a beverage and 20 as a medicine. All of the respondents who used the plant indicated that they would buy it if it were available for purchase in a store (Olivier, personal communication).

The potential toxicity of regularly consumed beverages, whether as a tea, tonic or a medicinal treatment, is an important consideration when studying the traditional use of plants. Various methods exist to investigate this toxicity, but as a rapid preliminary indication of possible adverse effects of traditional medicinal remedies, we screen extracts of plants in the brine shrimp larval toxicity and cell line cytotoxicity assays. Pyrrolizidine alkaloids (PAs) are one of the most important groups of toxins in plants. These compounds may occur in up to $3 \%$ of flowering plant species (Smith and Culvenor, 1981). Many members of the Asteraceae, especially Senecio species from the Senecioneae tribe, contain toxic PAs. Because the presence of PAs in food and beverages have very important health implications (Eloff et al., 2003), we determined whether PAs 
are present in Athrixia phylicoides although it belongs to a different tribe, Gnaphalieae of the Asteraceae.

Furthermore, the absence of caffeine is a desirable feature of a health beverage, as is the presence of antioxidants which may have beneficial health effects. Ivanova et al. (2005) reported that the roles of herbal tea in disease prevention and cure have been partly attributed to the antioxidant properties of phenolic compounds present in the extracts. Currently there is a widespread interest in the commercial development of plants with high levels of antioxidants, as foods or beverages. With this in mind we screened infusions, decoctions and extracts (aqueous and ethanol) of Athrixia phylicoides and Athrixia elata for cytotoxicity, presence of caffeine, phenols and antioxidant activity. Athrixia phylicoides, as the species selected for potential commercialization, was also tested for the presence of pyrrolizidine alkaloids.

\section{Materials and methods}

\subsection{Collection of plant material}

Two specimens of Athrixia phylicoides DC. were collected, one from the Dundee region of KwaZulu-Natal and the other from the Wolkberg, Limpopo province. Athrixia elata was collected in the vicinity of Makapansgat, Mokopane, Limpopo province. Identity of the specimens was verified by Mr. P. Winter (University of the North). Voucher specimens were accessioned to the South African National Biodiversity Institute, Pretoria and the Herbarium of the Department of Paraclinical Sciences (Medicinal Plant Collection) for Athrixia phylicoides (voucher no. PRE 592582.0) and Athrixia elata (voucher no. McGaw200501), respectively.

\subsection{Preparation of extracts}

\subsubsection{Cytotoxicity testing, antioxidant activity and phenolic content}

Decoctions of each species (Athrixia elata and Athrixia phylicoides collected from Limpopo) were prepared by boiling $50 \mathrm{~g}$ of dried aerial parts in $1.5 \mathrm{~L}$ water for $15 \mathrm{~min}$. Infusions were made by pouring $1.5 \mathrm{~L}$ boiling water over $50 \mathrm{~g}$ of dried aerial parts of each plant and allowing it to steep for $15 \mathrm{~min}$. This reflected the traditional method of preparation of decoctions and infusions. The preparations were left to cool before being 
filtered through Whatman No. 1 filter paper. Ethanol and water extracts were prepared by vigorous shaking of $1 \mathrm{~g}$ powdered, dried aerial parts with $10 \mathrm{~mL}$ of ethanol or distilled water. Owing to the fibrous, leathery nature of the leaves, the particle size of the ground leaves was not uniform and thus could not be accurately determined. The extracts were decanted, centrifuged at $1500 \times g$ for $10 \mathrm{~min}$ and filtered. The solvents were removed by drying in an oven at $40-50{ }^{\circ} \mathrm{C}$ under a stream of air. The extracts were weighed and reconstituted to a known concentration in ethanol or distilled water before assaying. The rationale behind the different methods of extract preparation is that investigation was aimed at comparing the biological activity of traditionally prepared decoctions and infusions with that of water and ethanol extracts prepared under controlled laboratory conditions. In particular, comparisons between hot water extracts (decoctions and infusions) and a cold water extract prepared in the laboratory were of interest. The extracts described in this section were used in the brine shrimp assay, Vero cell line cytotoxicity assay, antioxidant activity investigation and phenolic content assay.

\subsubsection{Caffeine detection}

The Athrixia elata and Athrixia phylicoides infusions and decoctions as well as the aqueous extracts ( $10 \mathrm{~mL}$ of each, as prepared in Section 2.2.1) were extracted using chloroform $(10 \mathrm{~mL})$. The chloroform phase was removed and evaporated in a stream of cold air. Extracts of regular tea (Joko), coffee (Nescafé instant coffee) and rooibos (Lipton) were prepared similarly. The ethanol extracts were used directly in the caffeine detection technique.

\subsubsection{Pyrrolizidine alkaloid screening}

The aerial parts of the two Athrixia phylicoides samples were dried and ground and $1 \mathrm{~g}$ extracted by suspension in $10 \mathrm{~mL}$ methanol which was allowed to stand for $24 \mathrm{~h}$ at room temperature. The suspension was centrifuged and the supernatant filtered through Whatman No. 1 filter paper and then passed through a $0.22 \mu \mathrm{m}$ filter (Waters Corporation, Milford, MA, USA). Senecio latifolius DC. (Asteraceae, voucher specimen accessioned to the South African National Biodiversity Institute, Pretoria) which is 
known to contain PAs, served as positive control and was prepared as described for Athrixia phylicoides.

\subsection{Experimental procedures}

\subsubsection{Cytotoxicity assay}

The plant extracts were tested for cytotoxicity against the Vero monkey kidney cell line (Department of Veterinary Tropical Diseases, University of Pretoria). The cells were maintained in minimal essential medium (MEM, Highveld Biological, Johannesburg, South Africa) supplemented with $0.1 \%$ gentamicin (Virbac) and 5\% foetal calf serum (Adcock-Ingram). To prepare the cells for the assay, cell suspensions were prepared from confluent monolayer cultures and plated at a density of $0.5 \times 10^{3}$ cells into each well of a 96-well microtitre plate. After overnight incubation at $37{ }^{\circ} \mathrm{C}$ in a $5 \% \mathrm{CO}_{2}$ incubator, the subconfluent cells in the microtitre plate were used in the cytotoxicity assay. Stock solutions of the plant extracts were prepared by reconstitution to a concentration of $100 \mathrm{mg} / \mathrm{mL}$. Serial 10-fold dilutions of each extract were prepared in growth medium (1$1000 \mu \mathrm{g} / \mathrm{mL}$ ). The viable cell growth after $120 \mathrm{~h}$ incubation with plant extracts was determined using the tetrazolium-based colorimetric assay (MTT assay) described by Mosmann (1983). The absorbance was measured on a Titertek Multiscan MCC/340 microplate reader at $540 \mathrm{~nm}$ test wavelength and reference wavelength of $690 \mathrm{~nm}$. Berberine chloride (Sigma Chemical Company) was used as a positive control. Tests were carried out in quadruplicate and each experiment was repeated three times.

\subsubsection{Brine shrimp larval mortality assay}

Athrixia extracts were tested against Artemia salina Lech. (brine shrimp) larvae following the method of Solís et al. (1993). Brine shrimp eggs were purchased from a local pet shop and hatched in artificial sea water $(3.8 \% \mathrm{NaCl})$. Plant extracts were tested at concentrations of $0.1,0.2,0.5,1,2$ and $5 \mathrm{mg} / \mathrm{mL}$. Podophyllotoxin (Sigma Chemical Company) was used as positive control. The number of dead and live nauplii in each well was counted using a stereomicroscope. If control deaths occurred, the percent death values were corrected using Abbott's formula as expressed by Rasoanaivo and 
Ratsimamanga-Urverg (1993). Tests were carried out in triplicate and the experiments were repeated three times.

\subsubsection{Antioxidant assay}

The TEAC (Trolox equivalent antioxidant capacity) assay described by Re et al. (1999) was used to detect antioxidant activity in the Athrixia extracts. The oxidant, $\mathrm{ABTS}^{+}$, was generated by persulfate oxidation of 2,2'-azinobis(3-ethylbenzothiazoline-6-sulfonic acid) (ABTS, Sigma). In this method $7 \mathrm{mM}$ ABTS in water was reacted with $2.45 \mathrm{mM}$ potassium persulfate and allowed to stand at room temperature for $12-16 \mathrm{~h}$ after which it was stored at $4{ }^{\circ} \mathrm{C}$ until needed. The solution was diluted with ethanol to an absorbance reading of $0.7( \pm 0.02)$ at $734 \mathrm{~nm}$. Initial dilutions of the test samples were prepared $(0.5$, 1 and $2 \mathrm{mg} / \mathrm{mL}$ ) in ethanol or water. A Trolox (6-hydroxy-2,5,7,8-tetramethylchromane2-carboxylic acid; Fluka) standard curve was prepared using absorbance at $734 \mathrm{~nm}$ (Thermo Electron Corporation Helios $\beta$ Spectrophotometer). To calculate the TEAC, the gradient of the plot of the percentage inhibition of absorbance versus concentration plot for the substance under investigation is divided by the gradient of the plot for Trolox ( $R e$ et al., 1999). As a result, the TEAC of a substance is a relative value and has no units. Tests were carried out in triplicate and repeated three times.

To detect the number of antioxidant compounds present in the extracts, $100 \mu \mathrm{g}$ of the aqueous and ethanolic extracts were separated on a TLC plate (Merck aluminium-backed plates Silica gel $60 \mathrm{~F}_{254}$ ) using the solvent system ethyl acetate:methanol:water (100:13.5:10). After drying in a stream of cold air, the TLC plate was sprayed with $0.2 \%$ DPPH (1,1-diphenyl-2-picryl-hydrazyl, Sigma) in methanol. The presence of antioxidant compounds was revealed within 5 min as pale yellow zones against a purple background.

\subsubsection{Phenolic content}

The total phenol content was assayed according to the Folin-Ciocalteu method (Singleton and Rossi, 1965 and Singleton et al., 1999). Test samples were diluted to a concentration of $1 \mathrm{mg} / \mathrm{mL}$ in water or ethanol, depending on the extracting solvent. Test solution ( $0.05 \mathrm{~mL}$ of $1 \mathrm{mg} / \mathrm{mL}$ solution) was added to $3 \mathrm{~mL}$ of distilled water and swirled before adding $0.25 \mathrm{~mL}$ Folin-Ciocalteu phenol reagent (Sigma). After $2 \mathrm{~min}, 0.75 \mathrm{~mL}$ of $20 \%$ 
sodium carbonate (Sigma) was added and the volume made up to $5 \mathrm{~mL}$ with distilled water. The mixture was vortexed and left for $2 \mathrm{~h}$, after which the absorbance was measured at $760 \mathrm{~nm}$. The mixture without test solution was used as a blank. A $1 \mathrm{mg} / \mathrm{mL}$ solution of gallic acid (Aldrich) in $40 \%$ ethanol was used as a standard, and the total phenolic content of each extract was expressed as a percentage of the phenolic content of gallic acid (taken as $100 \%$ ).

Spectrophotometric measurements were performed on a Thermo Electron Corporation Helios $\beta$ Spectrophotometer. The phenolic content determinations were performed at least three times for each separate concentration of standard and samples, and in triplicate.

\subsubsection{Caffeine detection}

The dried extracts, apart from the ethanol extracts, were re-suspended to a concentration of $10 \mathrm{mg} / \mathrm{mL}$ in chloroform. Ethanol extracts were re-suspended to $10 \mathrm{mg} / \mathrm{mL}$ in ethanol. Fifty micrograms of each extract were separated by TLC as described previously using the solvent system ethyl acetate:methanol:water (100:13.5:10). Separated components were investigated under visible and ultraviolet light (Camac Universal UV Lamp TL$600)$ at 254 and $365 \mathrm{~nm}$. For detection of caffeine, the TLC plate was first sprayed with $1 \mathrm{~g}$ potassium iodide and $1 \mathrm{~g}$ iodine dissolved in $100 \mathrm{~mL}$ ethanol, followed by spraying with a 1:1 mixture of $25 \% \mathrm{HCl}: 96 \%$ ethanol (I/HCl reagent; Wagner and Bladt, 1996). Caffeine zones were indicated by a dark-brown colour discernible in visible light. Commercial tea and coffee served as caffeine-containing positive controls and rooibos (containing no caffeine) as the negative control.

\subsubsection{Pyrrolizidine alkaloid screening}

The method of Mattocks (1967) was used to screen for the oxidized base of the three pyrroline structure. One millilitre of oxidising agent, consisting of $0.01 \mathrm{~mL}$ hydrogen peroxide $(30 \%, \mathrm{w} / \mathrm{v})$ stabilised with tetrasodium pyrophosphate $(20 \mathrm{mg} / \mathrm{mL})$ and made up to $20 \mathrm{~mL}$ with isoamylacetate, was added to $1 \mathrm{~mL}$ of the ethanolic plant extract. The sample was vortexed and $0.25 \mathrm{~mL}$ acetic anhydride added before heating the sample at $60{ }^{\circ} \mathrm{C}$ for $50-70 \mathrm{~s}$. The samples were left to cool to room temperature. One millilitre of 
Ehrlich reagent was added and the test tubes placed in a water bath $\left(60^{\circ} \mathrm{C}\right)$ for $5 \mathrm{~min}$. Absorbance was measured at $562 \mathrm{~nm}$ (Cintra 5, UV-VIS spectrophotometer, GBC Scientific Equipment, Melbourne, Virginia, Australia).

The method of Holstege et al. (1995) was used to confirm results of the screening method, using a Hewlett Packard 6890 gas chromatography-mass spectrometry (GCMS) system. Retrorsine (Sigma Chemical Company) was included as a standard. The chromatographic separation was performed with a J \& W Scientific DB-5 MS fused silica column $(30 \mathrm{~m} \times 0.25 \mathrm{~mm}$ i.d., film thickness $0.1 \mu \mathrm{m})$ (Folsom, CA, USA). The injector temperature was $280^{\circ} \mathrm{C}$, split ratio was $1: 50$; injection volume $2 \mu \mathrm{L}$ and the carrier gas helium. The temperature programme was as follows: $60^{\circ} \mathrm{C}$ for $1 \mathrm{~min}$ increasing to $280^{\circ} \mathrm{C}$ with a ramp rate of $5^{\circ} \mathrm{C} / \mathrm{min}$, where it was kept isothermally at $280^{\circ} \mathrm{C}$ for 20 min. Peaks were compared with the GC-MS library.

\section{Results}

The extraction yields of the Athrixia extracts are presented in Table 1. Generally, using ethanol as an extractant resulted in far lower masses of extracts than those obtained using water. The cytotoxic activities of the Athrixia extracts in the Vero monkey kidney cell line and in the brine shrimp assay are provided in Table 1. In both assays the ethanol extracts of Athrixia phylicoides and Athrixia elata were relatively toxic. However, aqueous extracts prepared in the laboratory, and decoctions and infusions of the plant material prepared following the traditional approach had no effect in both the brine shrimp lethality and MTT cytotoxicity assays at the concentrations tested. 
Table 1.

Antioxidant and cytotoxic activity of Athrixia extracts ( \pm S.D.)

\begin{tabular}{|c|c|c|c|c|c|c|}
\hline Species & Extract & $\begin{array}{l}\text { Yield } \\
\text { (mg/g) }\end{array}$ & $\begin{array}{l}\text { TEAC } \\
\text { content }^{\mathrm{a}}\end{array}$ & $\begin{array}{l}\text { Phenolic } \\
\text { content }\end{array}$ & $\begin{array}{l}\text { Brine } \\
\text { shrimp }^{b} \\
\text { LC }_{50} \\
(\mu \mathrm{g} / \mathrm{mL})\end{array}$ & $\begin{array}{l}\text { Vero cell } \\
\mathrm{LC}_{50} \\
(\mu \mathrm{g} / \mathrm{mL})\end{array}$ \\
\hline Athrixia elata & Infusion & 310.1 & $0.224 \pm 0.004$ & $47.71 \pm 2.79$ & $>1000$ & $>1000$ \\
\hline Athrixia elata & Decoction & 109.3 & $0.198 \pm 0.004$ & $40.77 \pm 1.52$ & $>1000$ & $>1000$ \\
\hline $\begin{array}{l}\text { Athrixia } \\
\text { phylicoides }\end{array}$ & Infusion & 109.9 & $0.248 \pm 0.012$ & $43.64 \pm 1.40$ & $>1000$ & $>1000$ \\
\hline $\begin{array}{l}\text { Athrixia } \\
\text { phylicoides }\end{array}$ & Decoction & 133.3 & $0.269 \pm 0.015$ & $45.18 \pm 1.71$ & $>1000$ & $>1000$ \\
\hline Athrixia elata & Water & 163.4 & $0.173 \pm 0.005$ & $35.69 \pm 0.31$ & $>1000$ & $>1000$ \\
\hline Athrixia elata & Ethanol & 14.6 & $0.167 \pm 0.003$ & $24.80 \pm 0.72$ & 283 & 102 \\
\hline $\begin{array}{l}\text { Athrixia } \\
\text { phylicoides }\end{array}$ & Water & 138.6 & $0.278 \pm 0.022$ & $56.59 \pm 0.70$ & $>1000$ & $>1000$ \\
\hline $\begin{array}{l}\text { Athrixia } \\
\text { phylicoides }\end{array}$ & Ethanol & 22.4 & $0.174 \pm 0.007$ & $36.73 \pm 0.56$ & 394 & 252 \\
\hline Tea & & & $0.308 \pm 0.022$ & $21.96 \pm 1.48$ & $>1000$ & $>1000$ \\
\hline Rooibos & & & $0.257 \pm 0.001$ & $35.64 \pm 0.66$ & $>1000$ & $>1000$ \\
\hline Podophyllotoxin & & & & & 7.02 & \\
\hline Berberine & & & & & & 9.73 \\
\hline
\end{tabular}

${ }^{a}$ Phenolic content expressed as $\%$ gallic acid.

${ }^{\mathrm{b}}$ Brine shrimp larval mortality assay.

${ }^{\mathrm{c}}$ Cytotoxicity against the Vero cell line.

The Athrixia phylicoides extracts were superior free radical scavengers in the TEAC antioxidant assay compared to Athrixia elata extracts (Table 1). Rooibos possessed better antioxidant activity than Athrixia elata, but slightly lower activity than Athrixia phylicoides. A similar tendency was noted concerning phenolic content (Table 1). No trend in phenolic content was apparent in the Athrixia elata and Athrixia phylicoides infusions and decoctions (hot water preparations) compared to the laboratory prepared aqueous extract (cold water preparation). However, the ethanol extracts, with consistently 
lower phenolic contents, appeared to extract fewer phenolic compounds than the aqueous extracts. In the TLC DPPH method, each of the water extracts, decoctions and infusions of Athrixia phylicoides and Athrixia elata displayed a similar profile of visible antioxidant compounds, numbering at least eight, at $R_{\mathrm{f}}$ values of $0.06,0.14,0.19,0.33$, $0.42,0.54,0.59$ and 0.71 . On the other hand, there were four visible antioxidant compounds in rooibos tea in the solvent system used, at $R_{\mathrm{f}}=0.22,0.28,0.33$ and 0.55 . The ethanol extracts had five antioxidant compounds with $R_{\mathrm{f}}$ values of $0.01,0.19,0.72$, 0.77 and 0.89 .

The presence of caffeine $\left(R_{\mathrm{f}}=0.34\right)$ was identified in the positive controls (commercial tea and coffee) but was not noted in the rooibos extract or any of the infusions, decoctions or extracts (aqueous and ethanol) of the Athrixia species tested. The screening method of Mattocks (1967) for the identification of $n$-oxide groups was negative for both Athrixia phylicoides samples and positive for Senecio latifolius. No pyrrolizidine alkaloids were detected when the total ions or characteristic ions (single ion monitoring of PAs) of the Athrixia samples were compared to the GC-MS library. The control plant Senecio latifolius contained the PA, retrorsine.

\section{Discussion}

Little is known about the chemistry of the genus Athrixia. Bohlmann and Zdero (1977) isolated the terpenoid derivatives norkaurenes and thymol, from Athrixia species. A secolabdane derivative was subsequently isolated from Athrixia elata (Bohlmann et al., 1982). Following the traditional use of Athrixia species in the preparation of pleasant-tasting beverages with many health benefits, a study has been undertaken in South Africa to determine the feasibility of commercializing Athrixia phylicoides tea. This paper reports on some aspects of the investigation.

The absence of caffeine in the Athrixia extracts tested in the present study is a positive attribute. Caffeine is reportedly the most widely consumed central nervous system stimulant (Nehlig et al., 1992) and has various physiological effects. As a result, knowledge of the caffeine content of foods and beverages is a desirable feature for consumers and health care professionals. A number of negative characteristics associated with caffeine intake have been documented, such as dependence and withdrawal 
symptoms, as well as effects on anxiety and sleep which vary according to individual sensitivity (Nehlig et al., 1992). As with rooibos tea, the lack of caffeine in Athrixia tea may permit its regular consumption with none of the adverse effects associated with excessive caffeine intake.

The consumption of herbal teas for the prevention or cure of disease, or simply for the maintenance of optimum health, is a long-standing practice among many communities. Antioxidant effects detected in herb teas are likely to contribute to their health-giving properties. Ross and Kasum (2002) described the health-promoting properties of polyphenols from plant origin, particularly flavonoids. Niwa and Miyachi (1986) attributed the health aspects of rooibos tea, which is fermented during processing, to the presence of phenolics and their associated antioxidant activity. As highlighted by Von Gadow et al. (1997), the phenolic composition of a tea extract is greatly influenced by processing, more specifically by fermentation. Athrixia plant material is not fermented before preparation and consumption of the tea. Fermentation may have an influence on the phenolic content of Athrixia extracts.

The TEAC assay is widely used to assess the total amount of radicals that can be scavenged by an antioxidant, i.e. the antioxidant capacity (Arts et al., 2004). In the present investigation, the decoction and infusion of Athrixia phylicoides revealed higher TEAC values than those for Athrixia elata. The TEAC of the Athrixia phylicoides decoction was higher than that obtained for rooibos and this trend was reflected also in the phenol content. In general, however, there appeared to be no consistent correlation between the TEAC and the phenolic content of the extracts tested. This was explained by Ivanova et al. (2005), who stated that compounds other than polyphenols may contribute to the water-soluble antioxidant capacity measured by the TEAC assay. It is also possible that not all polyphenolic compounds possess ABTS radical quenching activities (Ivanova et al., 2005). It has been suggested that more than one method of antioxidant testing should be employed to gain a fully comprehensive indication of antioxidant efficacy of test substances, and in addition, the extrapolation of in vitro data to in vivo situations is often difficult (Aruoma, 2003). Although care should be taken in interpreting the results obtained using the TEAC assay, it is increasingly used for screening compounds, food products and extracts for antioxidant activity, and is particularly useful in providing a 
ranking order of antioxidants (Van den Berg et al., 1999) despite limitations with reproducibility.

The TLC DPPH method of qualitative antioxidant detection showed that each of the water extracts of the two Athrixia species displayed eight compounds with similar $R_{\mathrm{f}}$ values possessing DPPH free radical scavenging activity. This indicates the presence of related antioxidant compounds in Athrixia phylicoides and Athrixia elata. Rooibos tea had fewer antioxidant compounds at different $R_{\mathrm{f}}$ values to those shown in Athrixia tea in the TLC solvent system used, thus implying the presence of different antioxidant compounds. Ethanol extracts had five zones of antioxidant activity, some with similar $R_{\mathrm{f}}$ values to those in the water extracts.

The biological activity of antioxidants has attracted much interest with regard to their protective role against free radical damage that may be the cause of many diseases including cancer (Nakayama et al., 1993). Marnewick et al. (2000) concluded that honeybush and rooibos herbal teas, in addition to being good dietary sources of natural antioxidants to counteract the damaging effects of free radicals, may also protect against mutagenesis. Shimoi et al. (1996) suggested that plant flavonoids, which show potent activity in vitro, also function as antioxidants in vivo, and their protective effects may be attributed to their scavenging ability towards free radicals. However, further investigation is required to clarify the mechanism of action of plant flavonoids in vivo (Shimoi et al., 1996). It is known that flavonoids possess other biological activities that may or may not be related to their radical scavenging capacity. Liu and Finley (2005) supported the use of cell culture models for antioxidant research, as in vitro assays for total antioxidant activity and total phenolic content do not account for cellular physiological conditions and do not consider bioavailability and metabolism of potentially active chemicals. The presence of cytotoxic compounds in Athrixia phylicoides as well as Athrixia elata was evaluated using the brine shrimp larval mortality assay and a cell line cytotoxicity assay. The brine shrimp larval mortality assay is widely accepted as a convenient probe for potential cytotoxicity and pharmacological activity in plants (Meyer et al., 1982 and McLaughlin et al., 1998). The assay shows a good correlation with cytotoxicity in cell lines such as 9KB, P388, L5178Y and L1210 (Meyer et al., 1982, McLaughlin, 1991, De Rosa et al., 1994 and McLaughlin et al., 1998). However, a drawback of the brine shrimp 
assay is the lack of data correlating lethal effects of test substances against brine shrimp larvae to mammalian toxicity. Toxicity of test substances in cell line assays is anticipated to yield more reliable results, but this does not obviate the need for toxicity studies in mammals.

In both brine shrimp and cell line assays, no cytotoxic activity was detected in the infusions, decoctions or the aqueous extracts. However, the ethanol extracts displayed adverse effects on both the brine shrimp larvae and Vero cells, with Athrixia elata showing a more pronounced effect than Athrixia phylicoides in each of the two assays. It is disturbing that extracts prepared by ethanol and water differed to such a large extent in their toxicity with the assays used. In the laboratory, ethanol tinctures are frequently prepared of herbal material that is traditionally used as aqueous extracts. These results indicate that even if both extractants are highly polar, it does not necessarily mean that ethanol extracts would be as safe as aqueous extracts used traditionally. Although cytotoxic effects of aqueous preparations of the two Athrixia species were not present, mutagenicity tests as well as acute and chronic in vivo toxicity tests may need to be carried out using rodent models to verify the lack of toxicity before commercialization of the tea. A salient point is that no reports of suspected toxic effects after many years of traditional use as a beverage have been discovered.

Pyrrolizidine alkaloids are the most important plant toxins associated with disease in humans and animals (Prakash et al., 1999). In Jamaica (Stuart and Bras, 1957), South Africa (Selzer and Parker, 1951) and in tropical countries, liver diseases such as cirrhosis have occurred due to the occasional or continued consumption of medicinal plants in the form of bush teas. These intoxications were all due to plants containing PAs. Jamaican "bush tea" is prepared by a person going into the scrubland that dominates the flora of much of the island, to collect leaves, mainly Crotalaria species, which contain PAs (Huxtable, 1980). The presence of PAs in Symphytum officinale (comfrey) has resulted in the restriction of its internal medicinal use in many countries (Rode, 2002) with ensuing limitations on the commercial success of comfrey preparations. This serves as a precedent providing an obstacle to the commercialization of any herbal medicine or beverage known to contain PAs. No PAs could be detected in Athrixia phylicoides, and 
therefore this plant does not pose the threat of consumers developing veno-occlusive liver disease.

The antioxidant effects comparable to rooibos, and the additional benefit of the absence of caffeine and cytotoxic effects, provide strong motivators for the development of Athrixia phylicoides as a herbal tea. Most significantly, these properties substantiate the use of Athrixia tea, both bush tea and daisy tea, as traditional health beverages.

\section{References}

Arts et al., 2004 M.J.T.J. Arts, J.S. Dallinga, H.-P. Voss, G.R.M.M. Haenen and A. Bast, A new approach to assess the total antioxidant capacity using the TEAC assay, Food Chemistry 88 (2004), pp. 567-570.

Aruoma, 2003 O.I. Aruoma, Methodological considerations for characterizing potential antioxidant actions of bioactive components in plant foods, Mutation Research 523-524 (2003), pp. 9-20.

Bohlmann and Zdero, 1977 F. Bohlmann and C. Zdero, Neue norkauren- und thymolderivate aus Athrixia-arten, Phytochemistry 16 (1977), pp. 1773-1776.

Bohlmann et al., 1982 F. Bohlmann, M. Wallmeyer and J. Jakupovic, A new secolabdane derivative from Athrixia elata, Phytochemistry 21 (1982), pp. 1806-1807. De Rosa et al., 1994 S. De Rosa, A. De Giulio and C. Iodice, Biological effects of prenylated hydroquinones: structure-activity relationship studies in antimicrobial, brine shrimp, and fish lethality assays, Journal of Natural Products 57 (1994), pp. 1711-1716. Eloff et al., 2003 J.N. Eloff, F.W. Jansen van Rijssen, T.W. Naude and J.P.J. Joubert, What levels of potentially toxic seed should be allowed in grains in South Africa? Part I. Background and pyrrolizidine alkaloid containing plants, South African Journal of Science 99 (2003), pp. 337-344.

Holstege et al., 1995 D.M. Holstege, J.N. Seiber and F.D. Galey, Rapid multiresidue screen for alkaloids in plant material and biological samples, Journal of Agricultural and Food Chemistry 43 (1995), pp. 691-699.

Hutchings et al., 1996 A. Hutchings, A.H. Scott, G. Lewis and A. Cunningham, Zulu Medicinal Plants: an Inventory, University of Natal Press, Pietermaritzburg (1996) p. $320-321$. 
Huxtable, 1980 R.J. Huxtable, Herbal teas and toxins: novel aspects of pyrrolizidine poisoning in the United States, Perspectives in Biology and Medicine 24 (1980), pp. 114.

Ivanova et al., 2005 D. Ivanova, D. Gerova, T. Chervenkov and T. Yankova, Polyphenols and antioxidant capacity of Bulgarian medicinal plants, Journal of Ethnopharmacology 96 (2005), pp. 145-150.

Leistner, 2000 O.A. Leistner, Seed Plants of Southern Africa: Families and Genera. Strelitzia 10, National Botanical Institute, Pretoria (2000) p. 125.

Liu and Finley, 2005 R.H. Liu and J. Finley, Potential cell culture models for antioxidant research, Journal of Agricultural and Food Chemistry 53 (2005), pp. 4311-4314. Mabogo, 1990 Mabogo, D.E.N., 1990. The ethnobotany of the Vhavenda, MSc Thesis. University of Pretoria, Pretoria.

Marnewick et al., 2000 J.L. Marnewick, W.C.A. Gelderblom and E. Joubert, An investigation on the antimutagenic properties of South African herbal teas, Mutation Research 471 (2000), pp. 157-166.

Mattocks, 1967 A.R. Mattocks, Spectrophotometric determination of unsaturated pyrrolizidine alkaloids, Analytical Chemistry 39 (1967), pp. 443-447.

McLaughlin, 1991 J.L. McLaughlin, Crown gall tumours on potato discs and brine shrimp lethality: two simple bioassays for higher plant screening. In: K. Hostettman, Editor, Methods in Biochemistry, Assays for Bioactivity vol. 6, Academic Press, London (1991), pp. 1-32.

McLaughlin et al., 1998 J.L. McLaughlin, L.L. Rogers and J.E. Anderson, The use of biological assays to evaluate botanicals, Drug Information Journal 32 (1998), pp. 513524.

Meyer et al., 1982 B.N. Meyer, N.R. Ferrigni, J.E. Putnam, L.B. Jacobsen, D.E. Nichols and J.L. McLaughlin, Brine shrimp: a convenient general bioassay for active plant constituents, Journal of Medicinal Plant Research 45 (1982), pp. 31-34.

Mosmann, 1983 T. Mosmann, Rapid colorimetric assay for cellular growth and survival: application to proliferation and cytotoxicity assays, Journal of Immunological Methods 65 (1983), pp. 55-63. 
Nakayama et al., 1993 T. Nakayama, M. Yamada, T. Osawa and S. Kawakishi, Suppression of active oxygen-induced cytotoxicity by flavonoids, Biochemical Pharmacology 45 (1993), pp. 265-267.

Nehlig et al., 1992 A. Nehlig, J.-L. Daval and G. Debry, Caffeine and the central nervous system: mechanisms of action, biochemical, metabolic and psychostimulant effects, Brain Research Reviews 17 (1992), pp. 139-170.

Niwa and Miyachi, 1986 Y. Niwa and Y. Miyachi, Antioxidant action of natural health products and Chinese herbs, Inflammation 10 (1986), pp. 79-91.

Pooley, 1998 E. Pooley, A Field Guide to Wild Flowers of KwaZulu-Natal and the Eastern Region, Natal Flora Publications Trust, Durban (1998) p. 442.

Prakash et al., 1999 A.S. Prakash, T.N. Pereira, P.E.B. Reilly and A.A. Seawright, Pyrrolizidine alkaloids in human diet, Mutation Research 443 (1999), pp. 53-67. Rasoanaivo and Ratsimamanga-Urverg, 1993 P. Rasoanaivo and S. RatsimamangaUrverg, Biological Evaluation of Plants with Reference to the Malagasy Flora, Napreca, Madagascar (1993) pp. 9-43, 72-83.

Re et al., 1999 R. Re, N. Pellegrini, A. Proteggente, A. Pannala, M. Yang and C. RiceEvans, Antioxidant activity applying an improved ABTS radical cation decolorization assay, Free Radical Biology and Medicine 26 (1999), pp. 1231-1237.

Rode, 2002 D. Rode, Comfrey toxicity revisited, Trends in Pharmacological Sciences 23 (2002), pp. 497-499.

Ross and Kasum, 2002 J.A. Ross and C.M. Kasum, Dietary flavonoids: bioavailability, metabolic effects and safety, Annual Review of Nutrition 22 (2002), pp. 19-34.

Selzer and Parker, 1951 G. Selzer and R.G.F. Parker, Senecio poisoning exhibiting as Chiari's syndrome, American Journal of Pathology 21 (1951), pp. 885-900.

Shimoi et al., 1996 K. Shimoi, S. Masuda, B. Shen, M. Furugori and N. Kinae, Radioprotective effects of antioxidative plant flavonoids in mice, Mutation Research 350 (1996), pp. 153-161.

Singleton and Rossi, 1965 V.L. Singleton and J.A. Rossi, Colorimetry of total phenolics with phosphomolybdic-phosphotungstic acid reagents, American Journal of Enology and Viticulture 16 (1965), pp. 144-158. 
Singleton et al., 1999 V.L. Singleton, R. Orthofer and R.M. Lamuela-Raventós, Analysis of total phenols and other oxidation substrates and antioxidants by means of FolinCiocalteu reagent, Methods in Enzymology 299 (1999), pp. 152-178.

Smith and Culvenor, 1981 L.W. Smith and C.C.J. Culvenor, Plant sources of hepatotoxic pyrrolizidine alkaloids, Journal of Natural Products 44 (1981), pp. 129-152.

Solís et al., 1993 P.N. Solís, C.W. Wright, M.M. Anderson, M.P. Gupta and J.D. Phillipson, A microwell cytotoxicity assay using Artemia salina (brine shrimp), Planta Medica 59 (1993), pp. 250-252.

Stuart and Bras, 1957 K.L. Stuart and G. Bras, Veno-occlusive disease of the liver, Quarterly Journal of Medicine 26 (1957), pp. 291-315.

Van den Berg et al., 1999 R. Van den Berg, G.R.M.M. Haenen, H. van den Berg and A. Bast, Applicability of an improved Trolox equivalent antioxidant capacity (TEAC) assay for evaluation of antioxidant capacity measurements of mixtures, Food Chemistry 66 (1999), pp. 511-517.

Van Wyk and Gericke, 2000 B.-E. Van Wyk and N. Gericke, People's Plants, Briza, Pretoria (2000) p. 102.

Von Gadow et al., 1997 A. Von Gadow, E. Joubert and C.F. Hansmann, Comparison of the antioxidant activity of rooibos tea (Aspalathus linearis) with green, oolong and black tea, Food Chemistry 60 (1997), pp. 73-77.

Wagner and Bladt, 1996 H. Wagner and S. Bladt, Plant Drug Analysis: a Thin Layer Chromatography Atlas (2nd ed.), Springer-Verlag, Berlin (1996) p. 50-51.

Watt and Breyer-Brandwijk, 1962 J.M. Watt and M.G. Breyer-Brandwijk, Medicinal and Poisonous Plants of Southern and Eastern Africa (2nd ed.), Livingstone, Edinburgh (1962) p. 203. 